\title{
A New Computer for Calculating the Water Content of Gases
}

\author{
A. W. Diniak and E. R. Weaver
}

\begin{abstract}
A new computer designed to reduce the labor in computing the water content of gases is described, and details of construction and use are given. The computer is of the circular slide-rule type with an accuracy of about that of a 10-inch slide rule. The computer consists of three disks with appropriate circular scales, which automatically correct for all deviations from ideality. It is a completely new design of an earlier model, and it is based on newly determined values for the corrections. The primary function of the computer is to calculate the water content and dewpoint of gases at pressures up to 6,000 pounds per square inch quickly, accurately, and with a minimum of effort, but it may be used for many other computations. Attention should be called to the fact that deviations from ideality are not dependent on methods of measurement and that they affect many measurements and computations in which they are usually ignored.
\end{abstract}

\section{Introduction}

Determining the water content of gases by the Weaver-electrical method $[1,2,3]^{1}$ involves the solution of the general equation

$$
W_{x}=W_{s} \frac{P_{w} P_{c}\left(1-K P_{c}+K^{\prime} P_{c}^{2}\right)}{P_{s}\left(1-K P_{s}+K^{\prime} P_{s}^{2}\right) P_{x}\left(1-K P_{x}+K^{\prime} P_{x}^{2}\right)}
$$

where $W_{x}$ is the unknown concentration (weight per unit volume) of water vapor in the gas being tested, $W_{s}$ is the concentration of water in the comparison gas at pressure $P_{s}$ (usually $W_{s}$ is the concentration of water vapor in equilibrium with liquid water or with ice, and $P_{s}$ is the pressure of saturation), $P_{c}$ is the absolute pressure of the comparison gas at which the fugacity of its water vapor is equal to that of the unknown gas at pressure $P_{x}, P_{w}$ is the pressure at which $W_{x}$ is to be expressed - usually $1 \mathrm{~atm}$, and $K$ and $K^{\prime}$ are constants, the values of which were determined experimentally [4] to be $K=1.9 \times 10^{-4}, K^{\prime}=$ $1.4 \times 10^{-8}$ for air and other gases (like oxygen and nitrogen) that behave similarly. All pressures in this equation are expressed in pounds per square inch absolute.

To solve the equation by longhand takes much more time than to make the measurements needed for a determination. To reduce the labor in making the necessary computations, a simple computer designed for the purpose may be used. The principle of the computer is not new; but it is a completely new design of an earlier model described by Weaver and Riley [1]. The computer is a circular slide rule consisting of three disks with appropriate circular scales inscribed on them. The several multiplications and divisions required for the solution of eq (1) are made by adding and subtracting angles proportional to the logarithms of the numbers indicated by the scales. Although the primary function of the computer is to solve the general equation for $W_{x}$ quickly, accurately, and with a minimum of effort, it may also be used for many other computations. The devia-

\footnotetext{
1 Figures in brackets indicate the literature references at the end of this paper.
}

tion from ideality that makes necessary the corrections involving $K$ and $K^{\prime}$ is, of course, a natural phenomenon that should not be ignored in work at high pressures, whatever the method of determining water vapor.

\section{General Arrangement of the Computer}

The computer consists of a base disk and two rotating disks with protruding tabs. Circular scales are arranged on the three disks in such a way that the general equation can be solved for $W_{x}$ with a minimum of manipulation. The computer is shown in figure 1.

\section{Base Disk}

The base disk (fig. 2) contains two scales, a logarithmic scale near its outer rim and a temperature scale near its center. Concentrations of water vapor are marked in milligrams per liter on the outer scale. Because this scale is a logarithmic scale like that of the ordinary slide rule, it can be used for a variety of computations involving, particularly, conversions from one unit to another. Data used in constructing the scale, and other details, are given in table 1.

On a relatively small circle on the base disk is a scale of Fahrenheit temperature, covering the range of $-30^{\circ}$ to $+120^{\circ} \mathrm{F}$. This scale is read through windows in the two upper disks. On it, angles are proportional to the logarithm of the vapor pressure of water at saturation at the temperatures marked on the scale. The arrangement of the temperature scale in relation to the outside scale and the markings on the latter require explanation.

It is the purpose of the computer to solve problems involving the compositions of gas mixtures (relative quantities of water vapor and of other gases), and it is convenient to express all compositions in terms of the weight of water in the quantity of mixture that would occupy unit volume under some standard condition, in this case $1 \mathrm{~atm}$ and $70^{\circ} \mathrm{F}$. If $p_{70}$ represents the vapor pressure of water at $70^{\circ} \mathrm{F}$, $W_{70}$ its density, and $p_{t}$ and $W_{t}$ the vapor pressure 


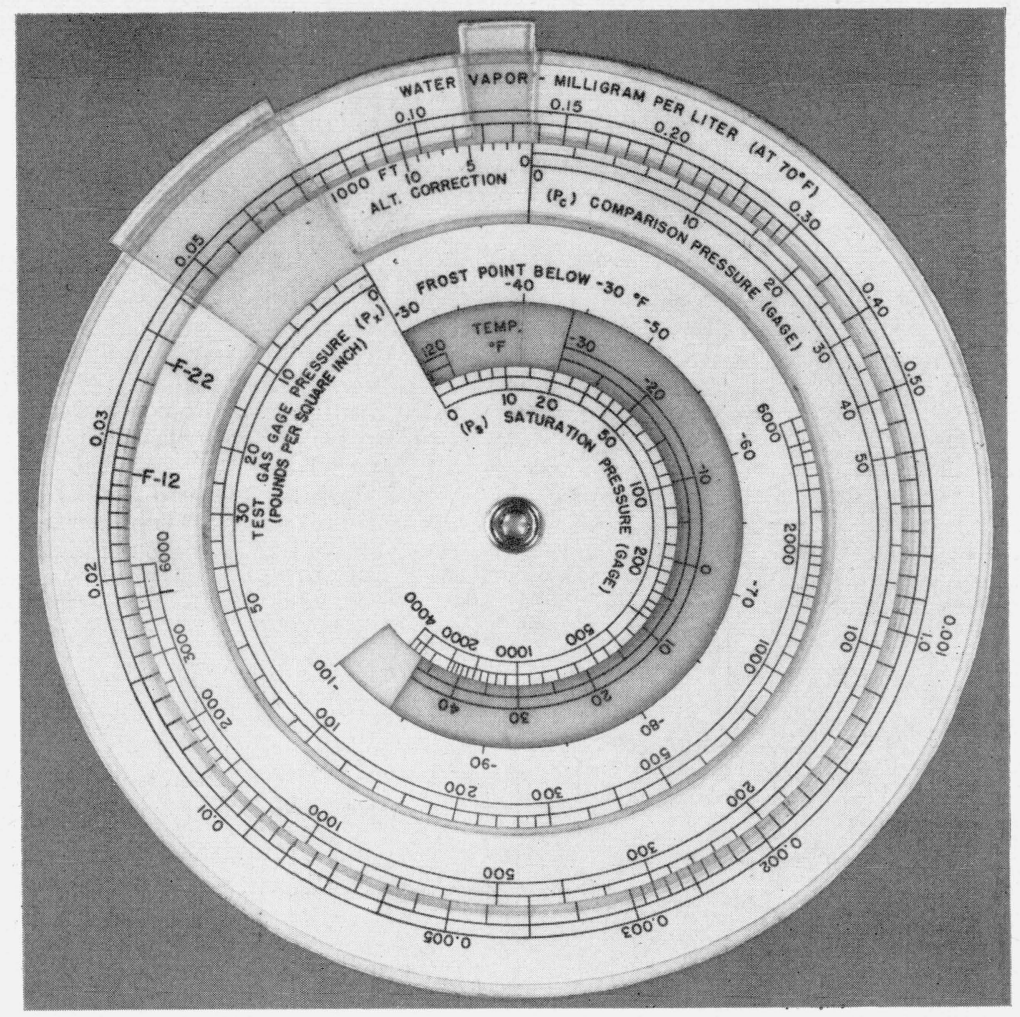

Figure 1. Assembled computer (approximately full size).

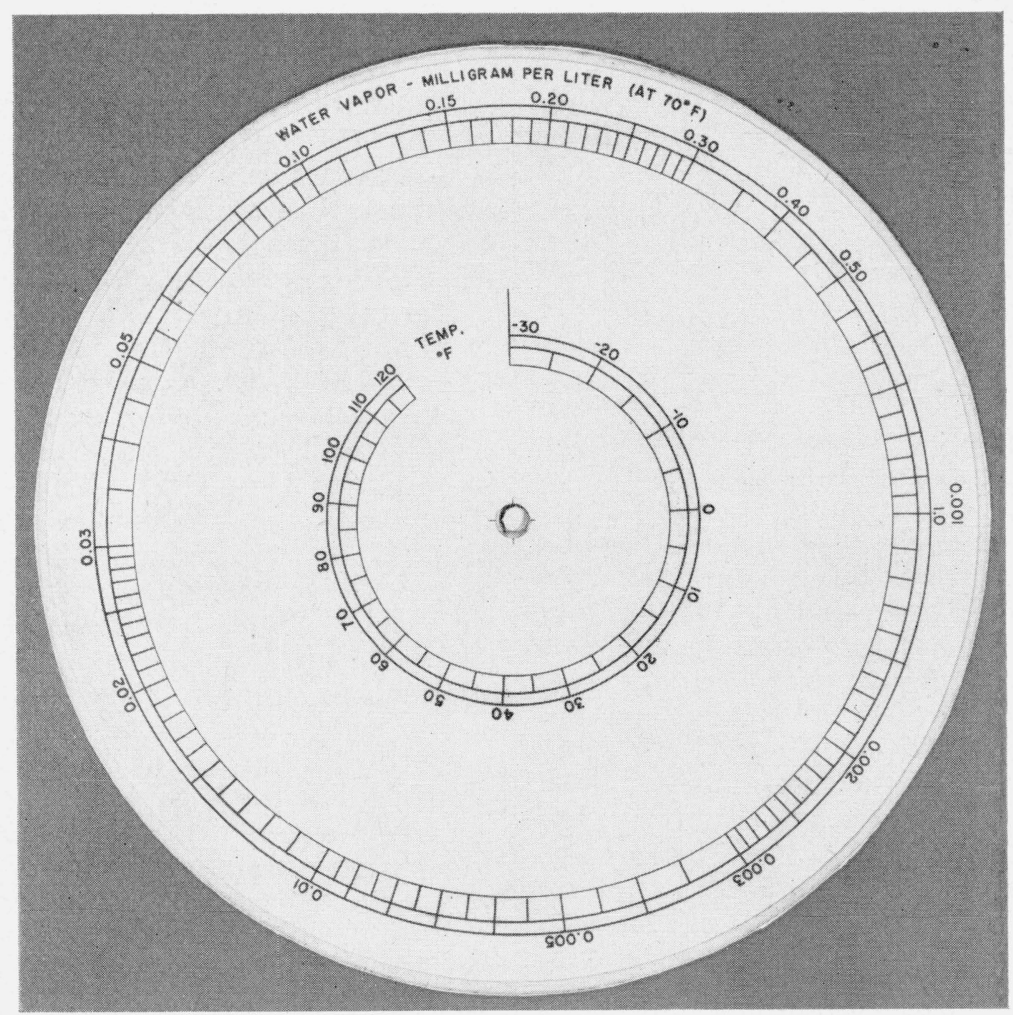

Figure 2. Base disk. 
TABLE 1. Data for outer logarithmic scale on base disk

(The scale is marked in milligrams of water vapor per liter at $70^{\circ} \mathrm{F}$.)

\begin{tabular}{|c|c|c|c|c|c|c|c|}
\hline \multirow{2}{*}{ No. } & \multirow{2}{*}{ Logarithm } & \multicolumn{2}{|c|}{ 1st cycle } & \multicolumn{2}{|c|}{2 d cycle } & \multicolumn{2}{|c|}{$3 \mathrm{~d}$ cycle } \\
\hline & & Angle a & Label & Angle & Label & Angle & Label on scale \\
\hline $\begin{array}{l}1.0 \\
1.1 \\
1.2 \\
1.3 \\
1.4\end{array}$ & $\begin{array}{r}0.0000 \\
.0414 \\
.0792 \\
.1139 \\
.1461\end{array}$ & $\begin{array}{r}d e g \\
0.0 \\
5.0 \\
9.5 \\
13.7 \\
17.5\end{array}$ & $1.0,0.001^{\mathrm{b}}$ & $\begin{array}{c}\text { deg } \\
120.0 \\
125.0 \\
129.5 \\
133.7 \\
137.5\end{array}$ & $\begin{array}{c}0.01 \\
\\
\end{array}$ & $\begin{array}{c}\text { deg } \\
240.0 \\
245.0 \\
249.5 \\
253.7 \\
257.5\end{array}$ & $\begin{array}{c}0.10 \\
\\
\end{array}$ \\
\hline $\begin{array}{l}1.5 \\
1.6 \\
1.7 \\
1.8 \\
1.9\end{array}$ & $\begin{array}{l}.1761 \\
.2041 \\
.2304 \\
.2553 \\
.2788\end{array}$ & $\begin{array}{l}21.1 \\
24.5 \\
27.6 \\
30.6 \\
33.4\end{array}$ & - & $\begin{array}{l}141.1 \\
144.5 \\
147.6 \\
150.6 \\
153.4\end{array}$ & - & $\begin{array}{l}261.1 \\
264.5 \\
267.6 \\
270.6 \\
273.4\end{array}$ & 0.15 \\
\hline $\begin{array}{l}2.0 \\
2.1 \\
2.2 \\
2.3 \\
2.4\end{array}$ & $\begin{array}{l}.3010 \\
.3222 \\
.3424 \\
3617 \\
.3802\end{array}$ & $\begin{array}{l}36.1 \\
38.7 \\
41.1 \\
43.4 \\
45.6\end{array}$ & 0.002 & $\begin{array}{l}156.1 \\
158.7 \\
161.1 \\
163.4 \\
165.6\end{array}$ & 0.02 & $\begin{array}{l}276.1 \\
278.7 \\
281.1 \\
283.4 \\
285.6\end{array}$ & 0.20 \\
\hline $\begin{array}{l}2.5 \\
2.6 \\
2.7 \\
2.8 \\
2.9\end{array}$ & $\begin{array}{l}.3979 \\
.4150 \\
.4314 \\
.4472 \\
.4624\end{array}$ & $\begin{array}{l}47.7 \\
49.8 \\
51.8 \\
53.7 \\
55.5\end{array}$ & מ & $\begin{array}{l}167.7 \\
169.8 \\
171.8 \\
173.7 \\
175.5\end{array}$ & מ & $\begin{array}{l}287.7 \\
289.8 \\
291.8 \\
293.7 \\
295.5\end{array}$ & - \\
\hline $\begin{array}{l}3.0 \\
3.5 \\
4.0 \\
4.5 \\
5.0\end{array}$ & $\begin{array}{l}.4771 \\
.5441 \\
.6021 \\
6532 \\
.6990\end{array}$ & $\begin{array}{l}57.2 \\
65.3 \\
72.2 \\
78.4 \\
83.9\end{array}$ & $\begin{array}{c}0.003 \\
0.005\end{array}$ & $\begin{array}{l}177.2 \\
185.3 \\
192.2 \\
198.4 \\
203.9\end{array}$ & $\begin{array}{c}0.03 \\
0.05\end{array}$ & $\begin{array}{l}297.2 \\
305.3 \\
312.2 \\
318.4 \\
323.9\end{array}$ & $\begin{array}{c}0.30 \\
0.50\end{array}$ \\
\hline $\begin{array}{l}5.5 \\
6.0 \\
6.5 \\
7.0 \\
7.5\end{array}$ & $\begin{array}{l}.7404 \\
.7782 \\
.8129 \\
.8451 \\
.8751\end{array}$ & $\begin{array}{r}88.8 \\
93.4 \\
97.5 \\
101.4 \\
105.0\end{array}$ & - & $\begin{array}{l}208.8 \\
213.4 \\
217.5 \\
221.4 \\
225.0\end{array}$ & - & $\begin{array}{l}328.8 \\
333.4 \\
337.5 \\
341.4 \\
345.0\end{array}$ & - \\
\hline $\begin{array}{r}8.0 \\
8.5 \\
9.0 \\
9.5 \\
10.0\end{array}$ & $\begin{array}{r}.9031 \\
.9294 \\
.9542 \\
.9777 \\
1.0000\end{array}$ & $\begin{array}{l}108.4 \\
111.5 \\
114.5 \\
117.3 \\
120.0\end{array}$ & $n_{0.01}$ & $\begin{array}{l}228.4 \\
231.5 \\
234.5 \\
237.3 \\
240.0\end{array}$ & 0.10 & $\begin{array}{l}348.4 \\
351.5 \\
354.5 \\
357.3 \\
360.0\end{array}$ & $1.0,0.001 \mathrm{~b}$ \\
\hline
\end{tabular}

ه The angles for the three cycles were calculated as follows:

For the 1st cycle: Angle $=120 \times \log$ of each number

For the 2d cycle: Angle=angle used in 1st cycle plus 120.

For the 3d cycle: Angle=angle used in 1st cycle plus 240.

b There are two labels on this mark.

and density at temperature $t$, and if the water vapor at this low pressure behaves as an ideal gas,

$$
\frac{W_{t}}{W_{70}}=\frac{p_{t}}{p_{70}} \frac{70+460}{t+460} .
$$

However, we are concerned not with the density (or concentration) of the water vapor at temperature $t$ but with its concentration, $W_{x}$, in the gas mixture at $70^{\circ} \mathrm{F}$ if the temperature is changed without gain or loss of vapor.

$$
\frac{W_{x}}{W_{t}}=\frac{t+460}{70+460},
$$

combining eq (2) and (3)

$$
\frac{W_{x}}{W_{70}}=\frac{p_{t}}{p_{70}} \frac{70+460}{t+460} \frac{t+460}{70+460}=\frac{p_{t}}{p_{70}} .
$$

Because of this direct proportionality, it is only necessary to arrange the two scales so that the logarithm of vapor pressure at $70^{\circ} \mathrm{F}$ is on the same radius as the logarithm of the concentration of water vapor at that temperature multiplied by a convenient power of 10 , and any other concentration "reduced" to $70^{\circ}$ will then be found on the same radius as its corresponding temperature. Because familiarity with the ideal gas law might make the reduction to $70^{\circ}$ easier to follow, that law was assumed in the derivation given. Actually, the result would have been the same had any other relation been assumed between temperature and gas density because, in the two steps of the reduction, the temperature factors cancel out. The reduction to $70^{\circ}$ only puts all measurements on the basis of a common unit of composition; it does not imply that gas saturated at a higher temperature can be cooled to $70^{\circ}$ without condensing some of the water.

Because the concentrations to be read in practice cover 5 or 6 orders of magnitude, whereas the circle is divided into only three decades, only values of the concentration (reduced to $70^{\circ} \mathrm{F}$ ) below $1 \mathrm{mg} /$ liter (at about $0^{\circ} \mathrm{F}$ ) are marked with their correct decimals. Above $1 \mathrm{mg}$ /liter the values of concentration opposite a given temperature are to be multiplied by 1,000 .

Detailed directions for laying off the temperature scale are given in table 2. The number 1.017 in the fifth column is that by which vapor pressure in millimeters of mercury at $70^{\circ} \mathrm{F}$ must be divided to obtain concentration in milligrams per liter. 
TABLE 2. Data for inner scale on base disk

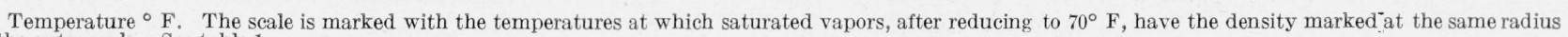
as the outer scale. See table 1.

\begin{tabular}{|c|c|c|c|c|c|c|c|c|}
\hline \multicolumn{2}{|c|}{ Temperature } & \multirow{2}{*}{$\begin{array}{c}\begin{array}{c}\text { Vapor } \\
\text { pressure }^{a}\end{array} \\
\\
m m \\
0.180 \\
.240 \\
.320 \\
.426 \\
.563\end{array}$} & \multirow{2}{*}{$\begin{array}{c}\begin{array}{c}\text { Log vapor } \\
\text { pressure }^{b}\end{array} \\
\\
\\
2.2553 \\
2.3802 \\
2.5052 \\
2.6294 \\
2.7505\end{array}$} & $\begin{array}{c}\begin{array}{c}\text { Conversion } \\
\text { factor }\end{array} \\
1.017\end{array}$ & $\begin{array}{c}\begin{array}{c}\text { Log } \\
\text { conversion } \\
\text { factor }\end{array} \\
0.0073\end{array}$ & \multirow{2}{*}{$\begin{array}{c}\mathrm{L} g \mathrm{~g} \\
\mathrm{mg} / \mathrm{liter} \\
\text { at } 70^{\circ} \mathrm{F}^{\mathrm{c}} \\
\\
\\
\\
\text { 2. } 2480 \\
2.3729 \\
2.4979 \\
2.6221 \\
2.7432\end{array}$} & \multirow{2}{*}{$\begin{array}{c}\text { Angle } \\
\\
\text { deg } \\
269.8 \\
284.7 \\
299.7 \\
314.6 \\
329.2\end{array}$} & \multirow{2}{*}{$\begin{array}{c}\begin{array}{c}\text { Label on } \\
\text { scale }\end{array} \\
\begin{array}{c} \\
-30 \\
-20 \\
-10\end{array}\end{array}$} \\
\hline $\begin{array}{c}\circ F \\
-30.0 \\
-25.0 \\
-20.0 \\
-15.0 \\
-10.0\end{array}$ & $\begin{array}{c}{ }^{\circ} C \\
-34.4 \\
-31.7 \\
-28.9 \\
-26.1 \\
-23.3\end{array}$ & & & $\begin{array}{c}1.017 \\
\cdots \\
\cdots \\
\cdots\end{array}$ & \begin{tabular}{c}
0.0073 \\
$-\ldots$. \\
\hdashline
\end{tabular} & & & \\
\hline $\begin{array}{c}-5.0 \\
0 \\
5.0 \\
10.0 \\
15.0\end{array}$ & $\begin{array}{r}-20.5 \\
-17.7 \\
-15.0 \\
-12.2 \\
-9.5\end{array}$ & $\begin{array}{r}.740 \\
.966 \\
1.241 \\
1.602 \\
2.039\end{array}$ & $\begin{array}{r}2.8692 \\
2.9850 \\
0.0938 \\
.2047 \\
.3094\end{array}$ & . & , & $\begin{array}{r}2.8619 \\
2.9777 \\
0.0865 \\
.1974 \\
.3021\end{array}$ & $\begin{array}{r}343.4 \\
357.3 \\
10.4 \\
23.7 \\
36.2\end{array}$ & $10^{0}$ \\
\hline $\begin{array}{l}20.0 \\
25.0 \\
30.0 \\
35.0 \\
40.0\end{array}$ & $\begin{array}{r}-6.7 \\
-3.9 \\
-1.1 \\
1.7 \\
4.4\end{array}$ & $\begin{array}{l}\text { 2. } 603 \\
\text { 3. } 308 \\
\text { 4. } 182 \\
\text { 5. } 181 \\
\text { 6. } 274\end{array}$ & $\begin{array}{l}.4155 \\
.5196 \\
.6214 \\
.7144 \\
.7975\end{array}$ & ' & - & $\begin{array}{l}.4082 \\
.5123 \\
.6141 \\
.7071 \\
.7902\end{array}$ & $\begin{array}{l}49.0 \\
61.5 \\
73.7 \\
84.8 \\
94.8\end{array}$ & 30 \\
\hline $\begin{array}{l}45.0 \\
50.0 \\
55.0 \\
60.0 \\
65.0\end{array}$ & $\begin{array}{r}7.2 \\
10.0 \\
12.8 \\
15.6 \\
18.4\end{array}$ & $\begin{array}{c}7.617 \\
9.209 \\
11.08 \\
13.29 \\
15.87\end{array}$ & $\begin{array}{r}.8817 \\
.9642 \\
1.0445 \\
1.1135 \\
1.2006\end{array}$ & - & . & $\begin{array}{r}.8744 \\
.9569 \\
1.0372 \\
1.1062 \\
1.1933\end{array}$ & $\begin{array}{l}104.9 \\
114.8 \\
124.5 \\
132.7 \\
143.2\end{array}$ & 60 \\
\hline $\begin{array}{l}70.0 \\
75.0 \\
80.0 \\
85.0 \\
90.0\end{array}$ & $\begin{array}{l}21.1 \\
23.9 \\
26.6 \\
29.4 \\
32.2\end{array}$ & $\begin{array}{l}18.76 \\
22.24 \\
26.12 \\
30.74 \\
36.07\end{array}$ & $\begin{array}{l}\text { 1. } 2732 \\
\text { 1. } 3471 \\
\text { 1. } 4170 \\
\text { 1. } 4877 \\
\text { 1. } 5572\end{array}$ & , & - & $\begin{array}{l}\text { 1. } 2659 \\
\text { 1. } 3398 \\
\text { 1. } 4097 \\
\text { 1. } 4804 \\
\text { 1. } 5499\end{array}$ & $\begin{array}{l}151.9 \\
160.8 \\
169.2 \\
177.6 \\
186.0\end{array}$ & $\begin{array}{c}70 \\
-80 \\
90\end{array}$ \\
\hline $\begin{array}{r}95.0 \\
100.0 \\
105.0 \\
110.0 \\
115.0\end{array}$ & $\begin{array}{l}35.0 \\
37.8 \\
40.6 \\
43.3 \\
46.1\end{array}$ & $\begin{array}{l}42.18 \\
49.16 \\
57.11 \\
65.82 \\
76.04\end{array}$ & $\begin{array}{l}\text { 1. } 6251 \\
\text { 1. } 6916 \\
\text { 1. } 7567 \\
\text { 1. } 8184 \\
1.8810\end{array}$ & - & - & $\begin{array}{l}\text { 1. } 6178 \\
1.6343 \\
1.7494 \\
1.8111 \\
1.8737\end{array}$ & $\begin{array}{l}194.1 \\
202.1 \\
209.9 \\
217.3 \\
224.8\end{array}$ & $100^{-1}$ \\
\hline 120.0 & 48.9 & 87.58 & 1. 9424 & 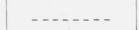 & - & 1. 9351 & 232.2 & 120 \\
\hline
\end{tabular}

a Obtained from International Critical Tables, vol. 3, p. 210-12 (1926 ed.)

In the first 7 entries 3.0000 was added to the logarithm for easier mathematical handling.

- Log milligrams per liter at $70^{\circ} \mathrm{F}=\log$ vapor pressure minus $\log$ conversion factor.

\section{Middle Disk}

The middle disk is shown in figure 3 . On the outer rim of the disk are located a pressure scale, an altitude scale, and two marks labeled F-12 and F-22. The pressure scale, which is marked Comparison Pressure $\left(P_{c}\right)$, extends about three-quarters of the way around the disk. Intervals of this scale are proportional to the effect of a gage pressure on the fugacity ${ }^{2}$ of water in the gas, and include corrections for the reduction of the fugacity of water vapor in the gas phase at high pressure and for the differences between gage pressure and absolute pressure. The scale was constructed by laying off angles corresponding to the logarithms of the adjusted absolute pressures, i. e., $P\left(1-K P+K^{\prime} P^{2}\right)$ instead of $P$. Each point is marked with the corresponding gage pressure (absolute pressure minus $14.7 \mathrm{psi}$ ). Data used in the construction of the pressure scale and other details are given in table 3 .

The altitude scale is used to correct the value of $W_{x}$ when $P_{c}$ is atmospheric pressure at a high altitude and is not directly measured. The correction is accomplished by subtracting an angle that corresponds nearly to the logarithm of the ratio of atmospheric pressure at the elevated altitude to

2 For the water vapor in two phases to be in equilibrium, it must have the same fugacity in each. For ideal gases fugacity is proportional to partial pressure. to atmospheric pressure at sea level. The construction and use of the scale will be explained more fully later.

The two marks labeled F-12 and F-22 are used in connection with moisture determinations in Freon12 and in Freon-22. Their use is explained in section 8 , dealing with conversion of units.

\section{Small Disk}

The small disk (fig. 4) contains two pressure scales, indentical in angular intervals with the comparison pressure scale on the middle disk. The inner, or saturation pressure $\left(P_{s}\right)$, scale is adjacent to the temperature scale on the base disk. The outer, or test gas pressure $\left(P_{x}\right)$, scale is arranged for convenient use in connection with the comparison pressure scale on the middle disk, but the sequence of numbers and their logarithms runs in the opposite direction. Each scale is the reciprocal of the other; that is, an angular displacement in the direction of increasing readings of one scale produces multiplication, and angular displacement in the direction of increasing numbers of the other scale results in division. The small disk also carries a scale of temperatures from $-30^{\circ}$ to $-100^{\circ} \mathrm{F}$ marked Frost Point below $-30^{\circ} \mathrm{F}$. It is, in effect, an extension of the temperature scale on the base disk and is used 


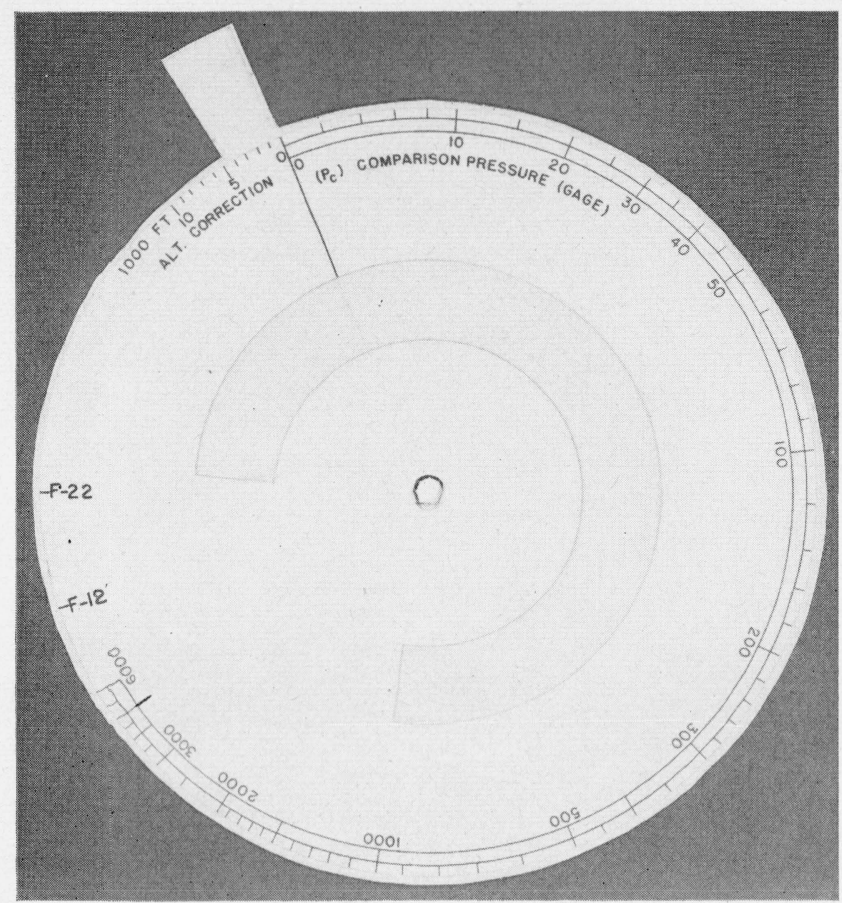

Figure 3. Middle disk.

by setting the temperature of interest at the -30 mark of the temperature scale and reading the -30 mark of the frost point scale. Data and other details for the three scales of the small disk are given in table 4 .

\section{Mathematical Operations}

The actual mathematical operations involved in solving eq (1) for $W_{x}$ with the computer are (a) divide $W_{s}$ by $P_{s}$ by subtracting the angle corresponding to the logarithm of $P_{s}$ from the angle corresponding to the logarithm of $W_{s}$, (b) multiply by $P_{w} / P_{x}$ by adding the angle corresponding to the difference between the logarithm of 14.7 (if $P_{w}$ is atmospheric pressure) and the logarithm of $P_{x}$, and, (c) multiply by $P_{c}$ by adding the angle corresponding to the logarithm of $P_{c}$. (All pressures involved in this operation are the adjusted pressures obtained by multiplying the absolute pressure in pounds per square inch by the factor $\left[1-K P+K^{\prime} P^{2}\right]$.) When $P_{w}$ is greater than atmospheric pressure, multiply by $P_{w} / 14.7$ by adding the angle corresponding to the difference between the logarithms of $P_{w}$ (not adjusted) ${ }^{3}$ and 14.7.

Problem 1 will serve to illustrate the most common use of the computer.

Problem 1: A high-pressure test gas containing an unknown amount of water $\left(W_{x}\right)$ is matched with a comparison gas that is saturated at a pressure of 1,000

3 Fugacity does not enter the correction of density for pressure, and the change can usually be assumed to be ideal. When dewpoints are calculated, the effect of gas pressure on fugacity must be considered, and $P_{w}$ is to be "adjusted" like the other pressures [4].

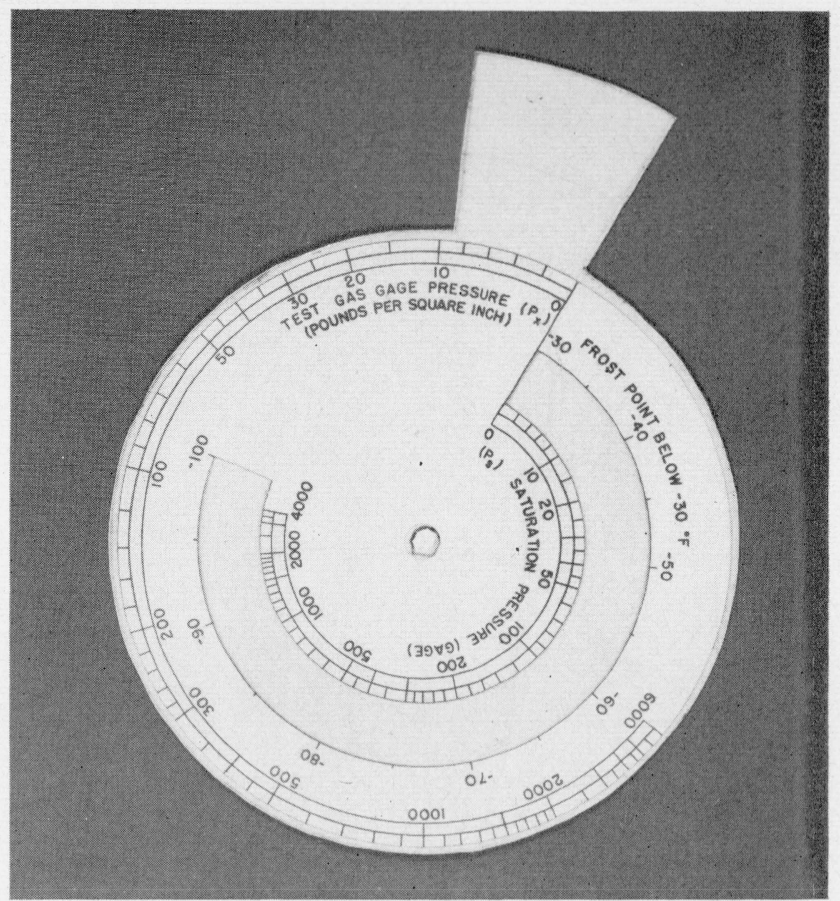

Figure 4. Upper (small) disk.

$\operatorname{psig}^{4}\left(P_{s}\right)$ and at a temperature of $60^{\circ} \mathrm{F}\left(T_{s}\right)$. Identical readings of the indicator show that the two gases have the same fugacity, that is, each is in equilibrium with the same third phase, when the test gas is at a pressure of $6,000 \mathrm{psig}\left(P_{x}\right)$ and the gas from the saturator is at a comparison pressure of 40 psig $\left(P_{c}\right)$. What is the water content $\left(W_{x}\right)$ of the test gas when expanded to one atmosphere at $70^{\circ} \mathrm{F}$ ? Solution: Opposite the saturation temperature $\left(T_{s}\right)$ of $60^{\circ} \mathrm{F}$ set the saturation pressure $\left(P_{s}\right)$ of 1,000 psig. Without disturbing the previous setting, set the 0 of the comparison pressure scale $\left(P_{c}\right)$ opposite the test gas pressure $\left(P_{x}\right)$ of 6,000 psig. Opposite the comparison pressure $\left(P_{c}\right)$ of 40 psig read the water content $\left(W_{x}\right)$ of $0.0058 \mathrm{mg} /$ liter at $70^{\circ} \mathrm{F}$. A second use of the computer is in the determination of temperatures of condensation (dewpoints or frost points), as will be illustrated by problems 2 and 3 :

Problem 2: What is the frost point of the gas considered in problem 1 when (a) discharged at atmospheric pressure, (b) reduced to a pressure of 100 psig? Solution: (a) Bring the right-hand edge of the wide tab to the water content at atmospheric pressure and $70^{\circ} \mathrm{F}, 0.0058 \mathrm{mg} /$ liter. Opposite $-30^{\circ}$ on the temperature scale, read $-81^{\circ}$ on the scale indicating "frost point below $-30^{\circ} \mathrm{F}$." (b) Bring the zero of the $P_{c}$ scale (the right-hand edge of the narrow tab) to $0.0058 \mathrm{mg} /$ liter. Bring the righthand edge of the wide tab to 100 psig on the $P_{c}$ scale. Opposite $-30^{\circ}$ of the temperature scale

4 Psig is the abbreviation for pounds per square inch gage i. e., above barometric pressure. 
TABLE 3. Data for comparison pressure scale on middle disk

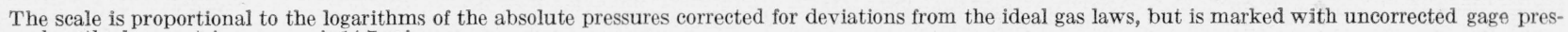
sures when the barometric pressure is $14.7 \mathrm{psi}$.

\begin{tabular}{|c|c|c|c|c|c|c|c|c|c|c|}
\hline \multicolumn{2}{|c|}{ Pressure } & \multirow{2}{*}{$\begin{array}{r}P^{2} \times 10^{-8} \\
0.00000216 \\
.00000279 \\
.00000350 \\
.00000428 \\
.00000515\end{array}$} & \multirow{2}{*}{$\begin{array}{c}K P \\
\left(1.9 \times 10^{-4} P\right) \\
\\
\\
0.0028 \\
.0032 \\
.0036 \\
.0039 \\
.0043\end{array}$} & \multirow{2}{*}{$\begin{array}{c}(1-K P) \\
\\
\\
\\
0.9972 \\
.9968 \\
.9964 \\
.9961 \\
.9957\end{array}$} & \multirow{2}{*}{$\begin{array}{c}K^{\prime} P^{2} \\
\left(1.4 \times 10^{-8} P^{2}\right) \\
\\
\\
\\
0 \\
0 \\
0 \\
0 \\
0\end{array}$} & \multirow{2}{*}{$\begin{array}{c}\left(1-K P+K^{\prime} P^{2}\right) \\
\\
\\
\\
0.9972 \\
.9968 \\
.9964 \\
.9961 \\
.9957\end{array}$} & \multirow{2}{*}{$\begin{array}{c}\text { Adjusted } \\
\text { pressure } \\
\\
\\
\text { psia } \\
14.7 \\
16.6 \\
18.6 \\
20.6 \\
22.6\end{array}$} & \multirow{2}{*}{$\begin{array}{c}\begin{array}{c}\text { Log of ad- } \\
\text { justed pressure } \\
-1.0000\end{array} \\
\\
0.1673 \\
.2201 \\
.2695 \\
.3139 \\
.3541\end{array}$} & \multirow{2}{*}{$\begin{array}{c}\text { Angle } \\
\\
\circ \\
20.1 \\
26.4 \\
32.3 \\
37.7 \\
42.5\end{array}$} & \multirow{2}{*}{$\begin{array}{c}\begin{array}{c}\text { Label } \\
\text { on scale }\end{array} \\
\\
\\
\end{array}$} \\
\hline $\begin{array}{r}\text { psig } \\
0 \\
2 \\
4 \\
6 \\
8\end{array}$ & $\begin{array}{l}p s i a \\
14.7 \\
16.7 \\
18.7 \\
20.7 \\
22.7\end{array}$ & & & & & & & & & \\
\hline $\begin{array}{l}10 \\
15 \\
20 \\
25 \\
30\end{array}$ & $\begin{array}{l}24.7 \\
29.7 \\
34.7 \\
39.7 \\
44.7\end{array}$ & $\begin{array}{l}.00000610 \\
.00000882 \\
.0000120 \\
.0000158 \\
.0000200\end{array}$ & $\begin{array}{l}.0047 \\
.0056 \\
.0066 \\
.0075 \\
.0085\end{array}$ & $\begin{array}{l}.9953 \\
.9944 \\
.9934 \\
.9925 \\
.9915\end{array}$ & $\begin{array}{l}0 \\
0 \\
0 \\
0 \\
0\end{array}$ & $\begin{array}{l}.9953 \\
.9944 \\
.9934 \\
.9925 \\
.9915\end{array}$ & $\begin{array}{l}24.6 \\
29.5 \\
34.5 \\
39.4 \\
44.3\end{array}$ & $\begin{array}{l}.2909 \\
.4698 \\
.5378 \\
.5955 \\
.6464\end{array}$ & $\begin{array}{l}46.9 \\
56.4 \\
64.5 \\
71.5 \\
77.6\end{array}$ & $\begin{array}{c}10 \\
20 \\
30\end{array}$ \\
\hline $\begin{array}{l}35 \\
40 \\
45 \\
50 \\
60\end{array}$ & $\begin{array}{l}49.7 \\
54.7 \\
59.7 \\
64.7 \\
74.7\end{array}$ & $\begin{array}{l}.0000247 \\
.0000299 \\
.0000356 \\
.0000419 \\
.0000558\end{array}$ & $\begin{array}{l}.0094 \\
.0104 \\
.0113 \\
.0123 \\
.0142\end{array}$ & $\begin{array}{l}.9906 \\
.9896 \\
.9887 \\
.9877 \\
.9858\end{array}$ & $\begin{array}{l}0 \\
0 \\
0 \\
0 \\
0\end{array}$ & $\begin{array}{l}.9906 \\
.9896 \\
.9887 \\
.9877 \\
.9858\end{array}$ & $\begin{array}{l}49.2 \\
54.1 \\
59.0 \\
63.9 \\
73.6\end{array}$ & $\begin{array}{l}.6920 \\
.7332 \\
.7708 \\
.8055 \\
.8669\end{array}$ & $\begin{array}{r}83.0 \\
88.0 \\
92.5 \\
96.7 \\
104.0\end{array}$ & 40 \\
\hline $\begin{array}{r}70 \\
80 \\
90 \\
100 \\
120\end{array}$ & $\begin{array}{r}84.7 \\
94.7 \\
104.7 \\
114.7 \\
134.7\end{array}$ & $\begin{array}{l}.0000717 \\
.0000897 \\
.000110 \\
.000132 \\
.000181\end{array}$ & $\begin{array}{l}.0161 \\
.0180 \\
.0199 \\
.0218 \\
.0256\end{array}$ & $\begin{array}{l}.9839 \\
.9820 \\
.9801 \\
.9782 \\
.9744\end{array}$ & $\begin{array}{l}0 \\
0.0001 \\
.0002 \\
.0002 \\
.0002\end{array}$ & $\begin{array}{l}.9839 \\
.9821 \\
.9803 \\
.9786 \\
.9746\end{array}$ & $\begin{array}{l}83.3 \\
93.0 \\
102.6 \\
112.2 \\
131.2\end{array}$ & $\begin{array}{r}.9206 \\
.9685 \\
1.0112 \\
1.0500 \\
1.1179\end{array}$ & $\begin{array}{l}110.5 \\
116.2 \\
121.3 \\
126.0 \\
134.1\end{array}$ & 100 \\
\hline $\begin{array}{l}140 \\
160 \\
180 \\
200 \\
220\end{array}$ & $\begin{array}{l}154.7 \\
174.7 \\
194.7 \\
214.7 \\
234.7\end{array}$ & $\begin{array}{l}.000239 \\
.000305 \\
.000379 \\
.000461 \\
.000574\end{array}$ & $\begin{array}{l}.0294 \\
.0332 \\
.0370 \\
.0408 \\
.0446\end{array}$ & $\begin{array}{l}.9706 \\
.9668 \\
.9630 \\
.9592 \\
.9554\end{array}$ & $\begin{array}{l}.0003 \\
.0004 \\
.0005 \\
.0006 \\
.0008\end{array}$ & $\begin{array}{l}.9709 \\
.9672 \\
.9635 \\
.9598 \\
.9562\end{array}$ & $\begin{array}{l}150.2 \\
169.0 \\
187.6 \\
206.1 \\
224.4\end{array}$ & $\begin{array}{l}1.1767 \\
1.2279 \\
1.2732 \\
1.3141 \\
1.3510\end{array}$ & $\begin{array}{l}141.2 \\
147.3 \\
152.8 \\
157.7 \\
162.1\end{array}$ & 200 \\
\hline $\begin{array}{l}240 \\
260 \\
280 \\
300 \\
350\end{array}$ & $\begin{array}{l}254.7 \\
274.7 \\
294.7 \\
314.7 \\
364.7\end{array}$ & $\begin{array}{l}.000648 \\
.000755 \\
.000868 \\
.000990 \\
.00133\end{array}$ & $\begin{array}{l}.0484 \\
.0522 \\
.0560 \\
.0598 \\
.0693\end{array}$ & $\begin{array}{l}.9516 \\
.9478 \\
.9440 \\
.9402 \\
.9307\end{array}$ & $\begin{array}{l}.0009 \\
.0011 \\
.0012 \\
.0014 \\
.0019\end{array}$ & $\begin{array}{l}.9525 \\
.9489 \\
.9452 \\
.9416 \\
.9326\end{array}$ & $\begin{array}{l}242.6 \\
260.7 \\
278.6 \\
296.3 \\
340.1\end{array}$ & $\begin{array}{l}1.3849 \\
1.4161 \\
1.4450 \\
1.4717 \\
1.5316\end{array}$ & $\begin{array}{l}166.2 \\
169.9 \\
173.4 \\
176.6 \\
183.8\end{array}$ & 300 \\
\hline $\begin{array}{l}400 \\
450 \\
500 \\
600 \\
700\end{array}$ & $\begin{array}{l}414.7 \\
464.7 \\
514.7 \\
614.7 \\
714.7\end{array}$ & $\begin{array}{l}.00172 \\
.00216 \\
.00265 \\
.00378 \\
.00511\end{array}$ & $\begin{array}{l}.0788 \\
.0883 \\
.0978 \\
.1168 \\
.1358\end{array}$ & $\begin{array}{l}.9212 \\
.9117 \\
.9022 \\
.8832 \\
.8642\end{array}$ & $\begin{array}{l}.0024 \\
.0030 \\
.0037 \\
.0053 \\
.0072\end{array}$ & $\begin{array}{l}.9236 \\
.9147 \\
.9059 \\
.8885 \\
.8714\end{array}$ & $\begin{array}{l}383.0 \\
425.1 \\
466.4 \\
546.2 \\
622.8\end{array}$ & $\begin{array}{l}1.5832 \\
1.6285 \\
\text { 1. } 6687 \\
\text { 1. } 7374 \\
1.7944\end{array}$ & $\begin{array}{l}190.0 \\
195.4 \\
200.2 \\
208.5 \\
215.3\end{array}$ & 500 \\
\hline $\begin{array}{r}800 \\
900 \\
1000 \\
1100 \\
1200\end{array}$ & $\begin{array}{l}814.7 \\
914.7 \\
1015 \\
1115 \\
1215\end{array}$ & $\begin{array}{l}.00664 \\
.00837 \\
.01030 \\
.01243 \\
.01476\end{array}$ & $\begin{array}{l}.1548 \\
.1738 \\
.1928 \\
.2118 \\
.2308\end{array}$ & $\begin{array}{l}.8452 \\
.8262 \\
.8072 \\
.7882 \\
.7692\end{array}$ & $\begin{array}{l}.0093 \\
.0117 \\
.0144 \\
.0174 \\
.0207\end{array}$ & $\begin{array}{l}.8545 \\
.8379 \\
.8216 \\
.8056 \\
.7899\end{array}$ & $\begin{array}{l}696.2 \\
766.8 \\
833.9 \\
898.2 \\
959.8\end{array}$ & $\begin{array}{l}1.8427 \\
1.8847 \\
1.9211 \\
1.9534 \\
1.9822\end{array}$ & $\begin{array}{l}221.1 \\
226.2 \\
230.5 \\
234.4 \\
237.9\end{array}$ & 1000 \\
\hline $\begin{array}{l}1300 \\
1400 \\
1500 \\
1600 \\
1700\end{array}$ & $\begin{array}{l}1315 \\
1415 \\
1515 \\
1615 \\
1715\end{array}$ & $\begin{array}{l}.01729 \\
.02002 \\
.02295 \\
.02608 \\
.02941\end{array}$ & $\begin{array}{l}.2498 \\
.2688 \\
.2878 \\
.3068 \\
.3258\end{array}$ & $\begin{array}{l}.7502 \\
.7312 \\
.7122 \\
.6934 \\
.6742\end{array}$ & $\begin{array}{l}.0242 \\
.0280 \\
.0321 \\
.0365 \\
.0412\end{array}$ & $\begin{array}{l}.7744 \\
.7592 \\
.7443 \\
.7299 \\
.7154\end{array}$ & $\begin{array}{l}1018 \\
1074 \\
1128 \\
1179 \\
1227\end{array}$ & $\begin{array}{l}2.0078 \\
2.0310 \\
2.0523 \\
2.0715 \\
2.0888\end{array}$ & $\begin{array}{l}240.9 \\
243.7 \\
246.3 \\
248.6 \\
250.6\end{array}$ & - \\
\hline $\begin{array}{l}1800 \\
1900 \\
2000 \\
2500 \\
3000\end{array}$ & $\begin{array}{l}1815 \\
1915 \\
2015 \\
2515 \\
3015\end{array}$ & $\begin{array}{l}.03294 \\
.03667 \\
.04060 \\
.06325 \\
.09090\end{array}$ & $\begin{array}{l}.3448 \\
.3638 \\
.3828 \\
.4778 \\
.5728\end{array}$ & $\begin{array}{l}.6552 \\
.6362 \\
.6172 \\
.5222 \\
.4272\end{array}$ & $\begin{array}{l}.0461 \\
.0513 \\
.0568 \\
.0886 \\
.1273\end{array}$ & $\begin{array}{l}.7013 \\
.6875 \\
.6740 \\
.6108 \\
.5545\end{array}$ & $\begin{array}{l}1273 \\
1317 \\
1358 \\
1536 \\
1672\end{array}$ & $\begin{array}{l}2.1048 \\
2.1196 \\
2.1329 \\
2.1864 \\
2.2232\end{array}$ & $\begin{array}{l}252.6 \\
254.4 \\
255.9 \\
262.4 \\
266.8\end{array}$ & 2000 \\
\hline $\begin{array}{l}3500 \\
4000 \\
4500 \\
5000 \\
5500\end{array}$ & $\begin{array}{l}3515 \\
4015 \\
4515 \\
5015 \\
5515\end{array}$ & $\begin{array}{l}.1236 \\
.1612 \\
.2038 \\
.2515 \\
.3042\end{array}$ & $\begin{array}{r}.6678 \\
.7628 \\
.8578 \\
.9528 \\
1.0478\end{array}$ & $\begin{array}{r}.3322 \\
.2372 \\
.1422 \\
.0472 \\
-.0478\end{array}$ & $\begin{array}{l}.1730 \\
.2257 \\
.2853 \\
.3521 \\
.4259\end{array}$ & $\begin{array}{l}.5052 \\
.4629 \\
.4275 \\
.3993 \\
.3781\end{array}$ & $\begin{array}{l}1776 \\
1858 \\
1930 \\
2002 \\
2085\end{array}$ & $\begin{array}{l}\text { 2. } 2494 \\
\text { 2. } 2690 \\
\text { 2. } 2856 \\
\text { 2. } 3015 \\
\text { 2. } 3191\end{array}$ & $\begin{array}{l}269.9 \\
272.3 \\
274.3 \\
276.2 \\
278.3\end{array}$ & - \\
\hline 6000 & 6015 & .3618 & 1. 1428 & -.1428 & .5065 & .3637 & 2188 & 2. 3400 & 280.8 & 6000 \\
\hline
\end{tabular}

a 1.0000 was subtracted from the logarithm for easier mathematical handling.

read $-52^{\circ}$ on the scale indicating "frost point below $-30^{\circ}$ F.'

Problem 3: Gas at a pressure of 100 psig is saturated with water vapor at $90^{\circ} \mathrm{F}$. What will be its dewpoint if expanded to 4 psig? Solution: Set 100 psig of the saturation pressure scale opposite $90^{\circ}$ of the Temperature scale. Opposite 4 psig on the saturation pressure Scale, read $40^{\circ} \mathrm{F}$, the dewpoint of the gas at 4 psig.

In a problem like those above, the test gas can be air, oxygen, nitrogen, or even Freon-12 at a pressure nearly up to its point of liquefaction, and the com- parison gas can be any of the first three gases. These four gases have negligibly different properties insofar as they affect moisture determinations. Further, the test gas can also be Freon-22, which does not behave like the others except at low pressures, provided certain restrictions are observed. For Freon-22 at pressures up to $30 \mathrm{psig}$, the computer will give moisture readings directly with negligible error. Above $30 \mathrm{psig}$, the readings become progressively erroneous with increase of pressure, but they can be corrected for any single pressure, as explained below in the section on conversion of units. 
The saturation pressure, $P_{s}$, scale is the same as the comparison pressure, $P_{c}$, scale except that it reads only to 4,000 psi, and some of the labels are omitted. Labels: $0,10,20,50,100,200,500,1000,2000,4000$.

Test Gas Pressure, $P_{2}$, Scale

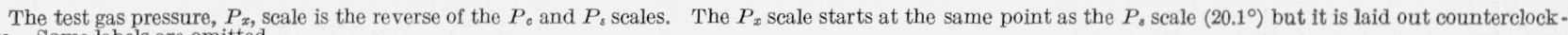
wise. Some labels are omitted.

Labels: $0,10,20,30,50,100,200,300,500,1000,2000,6000$.

Frost Point Below $-30^{\circ}$ F Scale

The scale is a continuation of the temperature scale arranged for convenient subtraction of angles from the point $-30^{\circ} \mathrm{F}$ of that scale.

\begin{tabular}{|c|c|c|c|c|c|c|c|c|c|}
\hline \multicolumn{2}{|c|}{ Temperature } & \multirow{2}{*}{$\begin{array}{l}\text { Vapor } \\
\text { pressure }\end{array}$} & \multirow{3}{*}{$\begin{array}{c}\text { Log vapor } \\
\text { pressurea } \\
\\
\text { 2. } 2497\end{array}$} & \multirow{3}{*}{$\begin{array}{c}\begin{array}{c}\text { Conver- } \\
\text { sion } \\
\text { factor }\end{array} \\
\\
1.02\end{array}$} & \multirow{3}{*}{$\begin{array}{l}\begin{array}{c}\text { Log con- } \\
\text { version } \\
\text { factor }\end{array} \\
0.0086\end{array}$} & \multirow{3}{*}{$\begin{array}{c}\begin{array}{c}\text { Log mg } \\
\text { per literb }\end{array} \\
\text { 2. } 2411\end{array}$} & \multirow{3}{*}{$\begin{array}{c}\text { Angle } \\
\text { A } \\
\\
\text { deg } \\
269\end{array}$} & \multirow{2}{*}{$\begin{array}{c}\underset{\mathrm{B}^{\circ}}{\text { Angle }} \\
\text { deg }\end{array}$} & \multirow{3}{*}{$\begin{array}{c}\text { Label } \\
\text { on scale } \\
\end{array}$} \\
\hline$-{ }^{\circ} \mathrm{F}$ & $-{ }^{\circ} \mathrm{C}$ & & & & & & & & \\
\hline 30 & 34.5 & 0.1777 & & & & & & 21 & \\
\hline 35 & 37.2 & .1323 & 2. 1216 & & - & 2. 1130 & 254 & 36 & \\
\hline 40 & 40.0 & .0966 & 1. 9850 & & & 1. 9764 & 237 & 53 & -40 \\
\hline 45 & 42.8 & .0682 & 1. 8338 & & & 1. 8252 & 219 & 71 & \\
\hline 50 & 45.6 & .0497 & 1. 6964 & - & & 1. 6878 & 202 & 88 & -50 \\
\hline 55 & 48.4 & .0360 & 1. 5563 & & & 1. 5477 & 186 & 104 & \\
\hline 60 & 51.1 & .0258 & 1. 4116 & -.. & & 1. 4030 & 167 & 123 & -60 \\
\hline 65 & 53.9 & .0180 & 1. 2553 & - & - & 1. 2467 & 150 & 140 & \\
\hline 70 & 56.8 & .0124 & 1. 0934 & & ......... & 1. 0848 & 130 & 160 & -70 \\
\hline 75 & 59.4 & .0087 & 0.9395 & & $-\cdots$ & 0.9309 & 112 & 178 & -....- \\
\hline 80 & 62.2 & .0059 & .7708 & & & .7622 & 92 & 198 & -80 \\
\hline 85 & 65.0 & .0040 & .6021 & $\ldots$ & ...... & .5935 & 71 & 219 & \\
\hline 90 & 67.7 & .0027 & .4314 & ....... & .......... & .4228 & 51 & 239 & -90 \\
\hline 95 & 70.5 & .0018 & .2553 & ...... & ........ & .2467 & 30 & 260 & \\
\hline 100 & 73.2 & .0012 & .0792 & ….. & $\ldots$ & .0706 & 8 & 282 & -100 \\
\hline
\end{tabular}

A 3.000 was added to logarithm for easier mathematical handling.

b Log milligrams per liter $=\log$ vapor pressure $-\log$ conversion factor.

- The angles in this column are oriented with respe ct to the -30 mark on the temperature scale on the base disk. $\mathrm{Angle} B=290^{\circ}-$ angle $\mathrm{A}$.

\section{Correction for Altitude (or Abnormal Barometric Pressure)}

The various pressure scales involve the reduction of gage pressures to absolute pressures and are correct only when the barometric pressures is $14.7 \mathrm{psia}$, the normal pressure at sea level. When the barometer differs significantly from normal, a correct result can be obtained by adding the barometric pressure to each pressure reading, subtracting $14.7 \mathrm{psi}$, and using the corrected pressures instead of the observed ones on the computer.

As an example of this correction and at the same time of the convenient use of the outside scale as a slide rule, assume that the gage readings of problem 1 were obtained when the barometer reading was 600 $\mathrm{mm}$ of mercury instead of the normal 760. The instrument will first be used as a slide rule to convert the pressure in millimeters of mercury to pounds per square inch. Set an edge of one of the tabs as a marker over 760 (multiplied by any convenient power of 10) and an edge of the other disk over 600 . Rotate the two disks together until the first marker reads 14.7. The second marker reads 11.6 , the barometric pressure in pounds per square inch. The difference between 14.7 and 11.6 is 3.1 and is to be subtracted from each gage reading. $P_{s}$ becomes 996.9 psig, $P_{\mathrm{x}}$ becomes 5,996.9 psig, and $P_{c}$ becomes 36.9 psig. When these corrected pressures are used and the setting otherwise made as before, the reading obtained is $0.0053 \mathrm{mg}$ /liter. In this case the correction of $P_{c}$ is the only significant one; the others are outside the limit of accuracy of gages or computer

The ordinary variations of the barometer at any one place can usually be neglected. Often the difference between the prevailing pressure at a testing station and sea level cannot. Corrections to sealevel conditions can always be made by the method described above, but this takes too much time when routine tests for compliance with a specification are being made. In the most convenient procedure for testing the dryness of compressed gases, the "comparison" gas is saturated at about 500 psig and is passed over the detector at or only slightly above atmospheric pressure to obtain $P_{c}$. The sample is then passed over the detector and its pressure, $P_{\mathrm{x}}$, is adjusted until the galvanometer reading is the same as that of the comparison gas at $P_{c}$.

Substantially all Government and many commercial specifications limit the water content of "dry" gases to $0.02 \mathrm{mg}(20 \mu \mathrm{g})$ per liter after expansion to 1 atm at $70^{\circ} \mathrm{F}$. A scale, marked Alt. Correction, has been added at the lower end of the $P_{c}$ scale by the use of which a gas that just meets the requirement of $0.02 \mathrm{mg} /$ liter will show the same analysis under average pressures at each altitude. The scale was obtained by comparing, for various altitudes, the concentration of water corresponding to the same set of gage readings when reduced to absolute pressures and entered in the general eq (1). For example, when a gas containing $0.02 \mathrm{mg} /$ liter at $1 \mathrm{~atm}$ and $70^{\circ} \mathrm{F}$ is measured by the procedure described when the barometric pressure is normal for sea level and the temperature is $70^{\circ} \mathrm{F}$, the gage readings 
TABLE 5. Altitude-correction scale

Angles are measured to left of 0 of scale.

\begin{tabular}{|c|c|c|c|c|c|c|}
\hline $\begin{array}{c}\text { Altitude, } \\
\text { A }\end{array}$ & $\begin{array}{l}\text { Barometric } \\
\text { pressure [5] }\end{array}$ & $\begin{array}{c}\text { Ratio of } \\
\text { pressures }\end{array}$ & Ratio $R$ & $\log R+1$ & Angle & $\begin{array}{l}\text { Label on } \\
\text { scale }\end{array}$ \\
\hline$f t$ & $m m \mathrm{Hg}$ & & & & deg & \\
\hline 0 & 760 & 1.000 & 1.000 & & 0 & 0 \\
\hline 1,000 & 732.9 & 0.964 & 0.966 & 0.985 & 1.8 & \\
\hline 2,000 & 706.6 & .930 & .933 & .970 & 3.6 & $\ldots$ \\
\hline 3,000 & 681.1 & .896 & .901 & .955 & 5.4 & ....... \\
\hline 4,000 & 656.3 & .864 & .871 & .940 & 7.2 & $\cdots$ \\
\hline 5,000 & 632.3 & .832 & .841 & .925 & 9.0 & 5 \\
\hline 6,000 & 609.0 & .801 & .811 & .909 & 10.92 & $\ldots$ \\
\hline 7,000 & 586.4 & .771 & .782 & .893 & 12.84 & - . \\
\hline 8,000 & 564.4 & .743 & .754 & .877 & 14. 76 & - \\
\hline 9,000 & 543.2 & .715 & .727 & .862 & 16.56 & ..... \\
\hline 10,000 & 522.6 & .688 & .701 & .846 & 18.48 & 10 \\
\hline
\end{tabular}

are $P_{s}=500$ psig, $P_{\mathrm{x}}=445 \mathrm{psig}, P_{c}=0$ psig. The normal barometric pressure at an altitude of 10,000 $\mathrm{ft}$ is 10.1 psig instead of the normal $14.7 \mathrm{psig}$ at sea level. By substituting corrected absolute pressures for the same gage readings in eq (1), we obtain, for sea level,

$$
\begin{aligned}
& \left(W_{x}\right)_{0}= \\
& 514.7\left(1-515 K+26523 K^{\prime}\right)(459.7)\left(1-460 K+21160 K^{\prime}\right),
\end{aligned}
$$

and for $10,000 \mathrm{ft}$,

$$
\begin{aligned}
& \left(W_{x}\right)_{0}= \\
& 510.1\left(1-510 K+26010 K^{\prime}\right)(455.1)\left(1-455 K+20703 K^{\prime}\right)
\end{aligned}
$$

from which

$$
\frac{\left(W_{x}\right)_{10000}}{\left(W_{x}\right)_{0}}=0.701 .
$$

Hence, the 10,000-ft mark of the altitude correction is placed at an angle below the zero of the correction scale corresponding to the logarithm of $1 / 0.701$. Table 5 shows the water contents corresponding to identical sets of gage pressures expressed as fractions of the water content at sea level computed in this manner. The alt. correction scale can be used with sufficient accuracy for most purposes if the comparison pressure is kept near atmospheric. However, when the comparison pressure is large, the alt. correction seale should not be used, but the gage pressures should be corrected for the abnormal barometric pressure, as described in the illustrative problem.

Table 6 shows the errors that result from failure to correct for altitude and from the use of the alt. correction scale in a number of typical cases. The last column in the table shows the correct result, computed from the basic eq (1).

\section{Conversion of Units}

The quantity of water in a gas is designated at

\begin{tabular}{|c|c|c|c|c|c|}
\hline \multicolumn{3}{|c|}{ Observed gage readings } & \multicolumn{3}{|c|}{ Computed value of $W$ ( $\mu \mathrm{g} /$ liter) } \\
\hline$P_{c}$ & $P_{s}$ & $P_{x}$ & $\begin{array}{l}\text { Uncorrected } \\
\text { for altitude }\end{array}$ & $\begin{array}{l}\text { Corrected by } \\
\text { "Alt" scale }\end{array}$ & $\begin{array}{c}\text { Corrected by } \\
\text { equation }\end{array}$ \\
\hline psig & psig & psig & & & \\
\hline 0 & 500 & & 28.58 & 20.00 & 20.00 \\
\hline 0 & & 450 & 20.08 & 14. 07 & 13. 90 \\
\hline 0 & 500 & 3,100 & 4. 951 & 3. 47 & 3. 43 \\
\hline 0 & 500 & 160 & 50.21 & 35.10 & 35.57 \\
\hline 0 & 3,500 & 100 & 20.08 & $\begin{array}{l}\text { 14. } 07 \\
14.0\end{array}$ & 14. 34 \\
\hline 32.5 & 500 & 2,000 & 19.82 & 13. 89 & 18.11 \\
\hline & 500 & 2,000 & 198.0 & 138.7 & 198.5 \\
\hline
\end{tabular}
various times and for several reasons by a variety of systems and units. It is often necessary or convenient to convert from one system to another.
TABLE 6. Corrected and uncorrected water content, $W$, of gases producing selected sets of gage readings at 10,000 feet and a temperature of $70^{\circ} \mathrm{F}$

The computer is designed to facilitate, particularly, interconversions among the following:

1. Weight of water per unit volume of gas at a standard temperature:

a. Milligrams per liter at $70^{\circ} \mathrm{F}$ (almost identical with ounces per 1,000 cubic feet).

b. Pounds per 10,000 cubic feet.

2. Weight of water per weight of gas:

a. Parts per thousand when the gas is air.

b. Parts per thousand when the gas is Freon12.

c. Parts per thousand when the gas is Freon22.

3. Vapor pressure of water.

4. Dewpoint (frost point below $32^{\circ} \mathrm{F}$ ).

5. Relative humidity.

6. Percentage by volume of vapor in gas.

The angular width of the large tab, on the small disk, is such that when the right edge (the 0 of the $P_{s}$ and $P_{x}$ scales) reads milligrams per liter, the left edge reads pounds per 10,000 cubic feet of gas on the outer scale of the base disk. The angular width is $24.7^{\circ}$, which is the angle corresponding to the logarithm of the factor for the conversion (see table $6)$.

The angular width of the narrow tab, on the middle disk, is such $\left(9.5^{\circ}\right)$ that when the right edge (the 0 of the $P_{c}$ scale) reads milligrams per liter of air, the left edge reads parts per thousand parts by weight of air.

The narrow tab can also be used for reading milligrams of water per liter of gas at a definite pressure when the gas is Freon-22. The ang lar width of the narrow tab is such that when the right edge reads the apparent water content in milligrams per liter at a pressure of $120 \mathrm{psig}$, the left edge reads the correct water content in the same units at the same pressure in Freon-22. This is an empirical relation discovered when using the computer for determining water in the refrigerant in question. Not contemplated in the design, it is nevertheless useful when working with this particular material. For pressures up to $30 \mathrm{psig}$, as mentioned above, the computer will give directly a close approximation to the correct moisture readings for Freon-22. When the zero of the comparison pressure scale indicates 


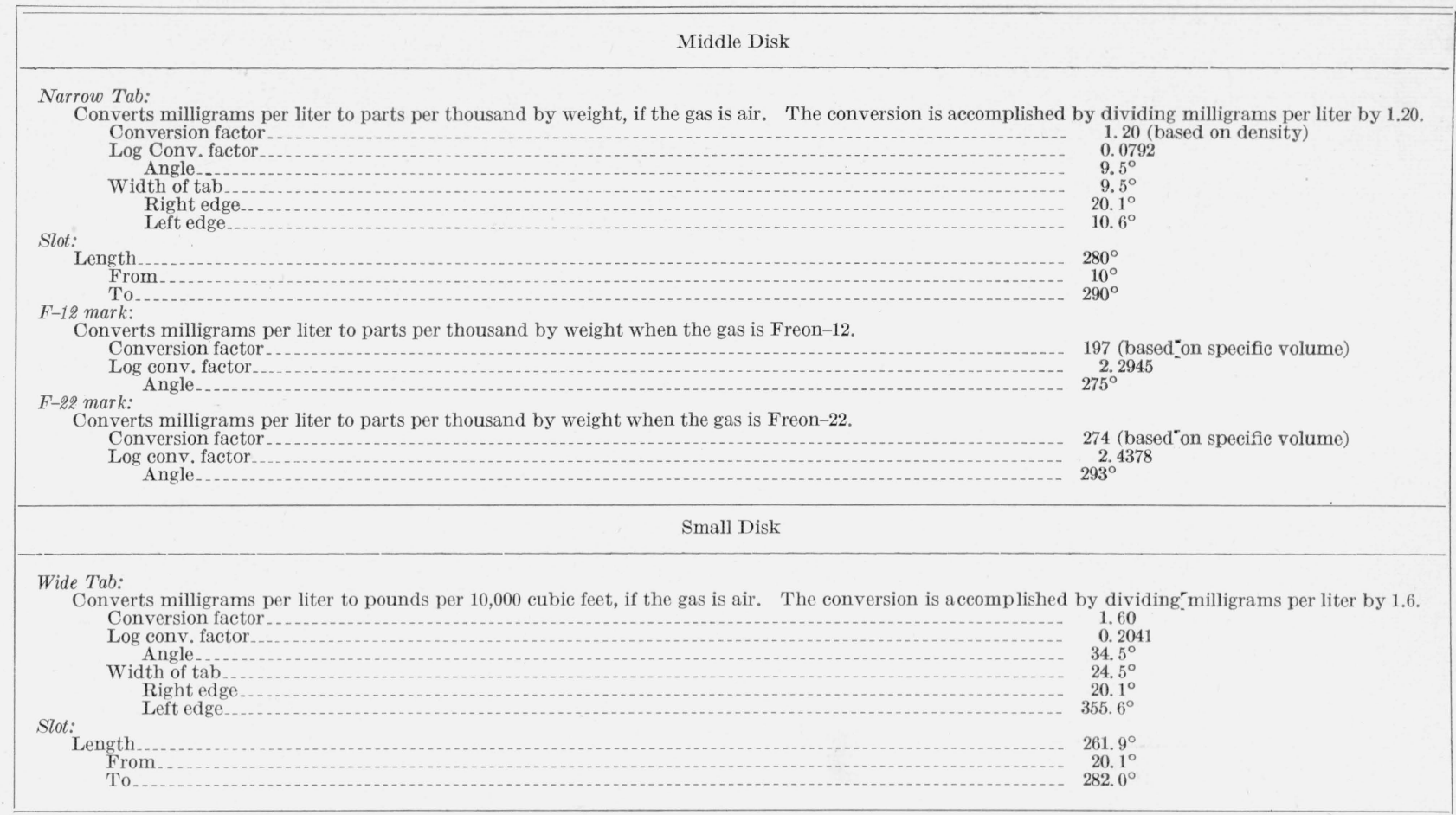

milligrams per liter at $70^{\circ} \mathrm{F}$, the 5,000 mark of the same scale (elongated to aid the memory) indicates percentage of water vapor by volume. This is another fortuitous coincidence.

The two marks labeled F-12 and F-22 are used to convert milligrams per liter to parts per thousand by weight (and parts per million, by moving the decimal point mentally) when the gas is Freon-12 or Freon-22. The angular distance between each labeled mark and the 0 mark of the comparison pressure scale corresponds to the logarithm of the factor of conversion. When the 0 mark reads milligrams per liter, the appropriate labeled mark reads parts per thousand by weight.

The vapor pressure of water in millimeters of mercury is numerically equal to 1.017 times the number of milligrams of water per liter at $70^{\circ} \mathrm{F}$. The difference between this factor and unity is readable on the computer, but is so small it can be neglected in many cases, and the outer scale read directly as vapor pressure.

If the water content is less than $1 \mathrm{mg}$ /liter, the dewpoint is read directly on the temperature scale under milligrams per liter on the outer scale. If the water content is more than $1 \mathrm{mg} /$ liter (at about $0^{\circ} \mathrm{F}$ ), the numbers on the outer scale must be multiplied by 1,000 to correspond to the dewpoint (frost point below $32^{\circ} \mathrm{F}$ ) on the adjacent temperature scale. If the right edge of the wide tab, on the upper disk, is brought to the water content in milligrams per liter on the outer scale, the frost point is read on the scale marked "Frost point below $-30^{\circ} \mathrm{F}$ " at the lowest point $\left(-30^{\circ} \mathrm{F}\right)$ on the temperature scale. The decimal point must be watched carefully in this operation; it is not taken care of automatically. Compare with problems 2 and 3 .

The relative amount of water in gases under two conditions is ascertained by finding an angle between the points representing concentrations under each condition. This angle can be set readily as that between the edges of the two protruding tabs. Then, if the middle disk is rotated, the small disk is carried along without disturbing the angle until one tab is above 1.0 of the outer scale on the base disk. The other tab then reads directly the ratio of concentration of water in the two cases. If one of the two conditions represents saturation, the ratio found is "relative humidity" as the term is ordinarily used.

Data for constructing the two tabs and the slots through which the temperature scale on the base disk is read, and for laying off the two marks labeled $\mathrm{F}-12$ and $\mathrm{F}-22$, are given in table 7.

\section{Construction of Computer}

The initial step in constructing the computer involves the making of large-sized ink drawings of each disk of the computer. These drawings are reduced photographically to the desired size, and the negatives are used to prepare stencils for use in an offset-printing press. The sections are printed on heavy white bond paper, and are permitted to dry overnight. The dry prints are cut out and trimmed with the aid of a special cutting tool similar to a beam compass, but with a sharp cutting edge instead of a drawing point. The cutouts are sandwiched 
between two layers of plastic for better wearability and easy handling. The sandwiching is perform ed on a laminating press, which uses heat and pressure to effect the bonding. The laminated sections are cut out and trimmed with the special cutting tool. The center holes are drilled on a drill press, c are being taken to center the holes accurately. T he three disks are assembled and a metal rivet is used to hold them together.

\section{References}

[1] E. R. Weaver and R. Riley, J. Research NBS 40, 169 (1948) RP1865.

[2] E. R. Weaver and R. Riley, Anal. Chem. 20, 216 (1948).

[3] E. R. Weaver, Anal. Chem. 23, 1076 (1951).

[4] A. W. Diniak and E. E. Hughes (publication pending).

[5] W. G. Brombacher, J. Wash. Acad. 34, 277 (1944).

Washington, June 23, 1955. 